\title{
A new variety of Abutilon persicum (Malvaceae) from southern Eastern Ghats, India
}

\author{
K. Devanathan* \\ ${ }^{1}$ Centre for Floristic Research, Department of Botany, Madras Christian College (Autonomous), Tambaram, \\ Chennai, Tamilnadu - 600 059, India. \\ *Email: deva.taxo@gmail.com
}

\begin{abstract}
A new variety of Abutilon persicum (Burm.f.) Merr. (Malvaceae) is described here from Kolli Hills, southern Eastern Ghats of Tamil Nadu, India. Detailed description, illustration and photo plate are provided to facilitate identification of this new variety.
\end{abstract}

Keywords: Abutilon persicum, New variety, Kolli Hills, Southern Eastern Ghats.

\section{Introduction}

The genus Abutilon Mill. comprises c. 120 species distributed in tropical and subtropical regions of both Old and New World (Mabberley, 2017). In India, it is represented by c. 18 taxa, of which five are endemic to India (Paul, 1993; Singh et al., 2015). Abutilon persicum (Burm.f.) Merr. is an eastern and southern Asiatic species that can be easily differentiated from other Indian Abutilon species by the conspicuous staminal filaments which are 3-4 times longer than the column, larger spreading corolla, acuminate and 4-6-seeded mericarps (Sivarajan \& Pradeep, 1996).

During the floristic exploration of Kolli Hills, and Eastern Ghats hill range, author has recognized populations of Abutilon persicum with distinct characteristic features. The collected specimens were compared with the herbarium images from $\mathrm{K}$ and specimens at CAL, CALI, FRLH, MH and RHT as well as with the descriptions provided by the authors of various floras and revisions (Dunn, 1915; Borssum Waalkes, 1966; Britto \& Matthew, 1983; Paul, 1993; Sivarajan \& Pradeep, 1996; Pullaiah \& Rao, 2002). After critical examination of the morphological characters, protologue and the type, the population has been identified as distinct hence described here as a new variety.

\section{Taxonomy}

Abutilon persicum var. narasimhanii Devanath., var. nov.

Figs. $1 \& 2$.

Abutilon persicum var. narasimhanii Devanath., is similar to the typical variety but differs from it in having shorter pedicel above the point of articulation; fruiting calyx covering $1 / 2$ or less than $1 / 2$ of the length of the schizocarp; 7 or 8 styles and mericarps and shorter mericarp awn (Table 1).

Type: INDIA, Tamil Nadu, Namakkal district, Kolli

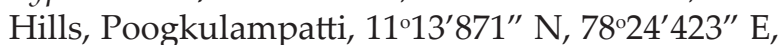
1000 m, 27.01.2017, Devanathan 11330 (Holo MH; Iso, CALI).

Shrubs, up to $5 \mathrm{~m}$ tall; branchlets softly stellatetomentose mixed with glandular-trichomes, sub-glabrous when mature. Leaves alternate, broadly ovate to suborbicular near the base, ovate-lanceolate above, 7-24 × 6-22 cm, deeply cordate at base, irregularly crenate to shallowlyincised at margins, caudate-acuminate at apex, stellate-tomentose admixed with simple trichomes above, densely stellate-tomentose admixed with simple trichomes beneath; veins 5-9, lower two veins bending downwards, rest arching towards margins; venation palmately netted; petioles 10-26 $\mathrm{cm}$ long, lower leaves with longer petioles, upper leaves with shorter petioles, stellate-tomentose mixed with long simple trichomes, glabrous when mature. Inflorescence axillary, solitary cymes initially, becoming terminal panicles towards maturity due to reduction of upper leaves, up to $2.5 \mathrm{~m}$ long. Flowers $2.5-3 \mathrm{~cm}$ across, yellow; pedicels in flowers $3-4 \mathrm{~cm}$ long, c. $5 \mathrm{~mm}$ long above the point of articulation; fruiting pedicels 4-5 $\mathrm{cm}$ long; 5-10 $\mathrm{mm}$ long above the point of articulation; stellately pubescent admixed with glandular-trichomes. Calyx campanulate, c. $1 \mathrm{~cm}$ across, stellate-tomentose admixed with glandular- 


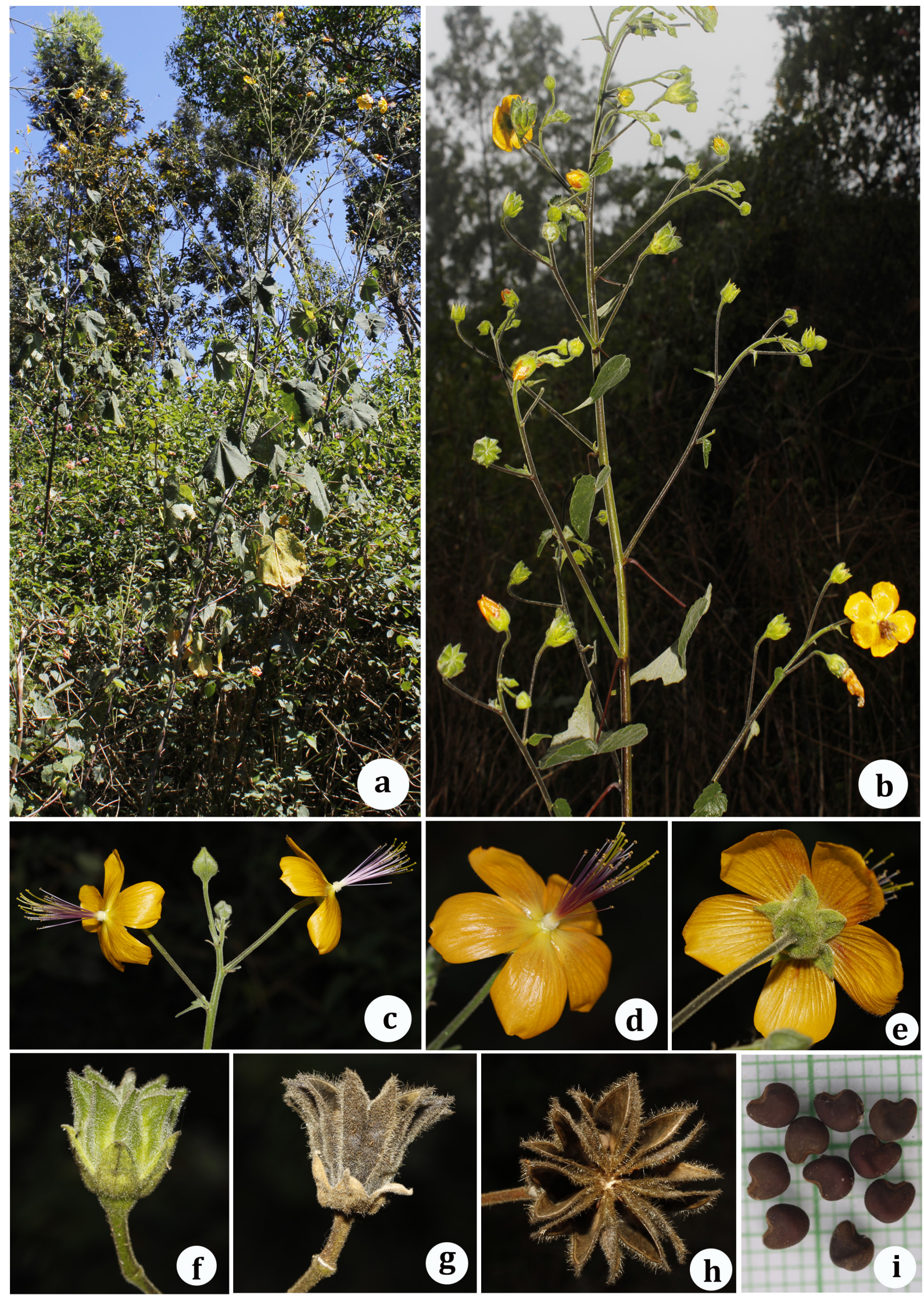

Figure 1. Abutilon persicum var. narasimhanii: a. Habit; b. Flowering twig; c. Flowers; d \& e. Flower-upper \& lower views; f \& g. Young \& mature schizocarps; $\mathbf{h}$. Dehisced schizocarp-top view; i. Seeds. 


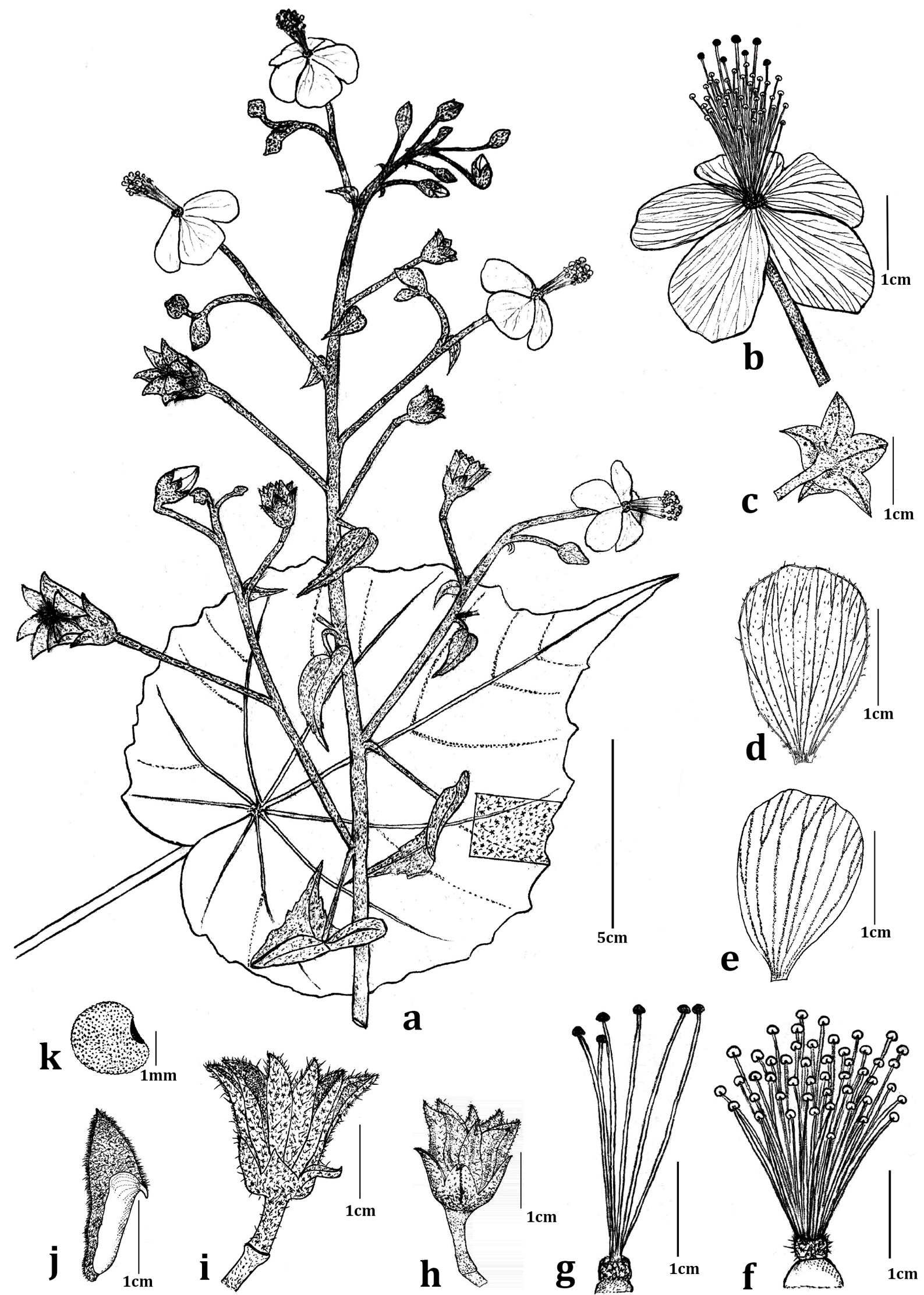

Figure 2. Abutilon persicum var. narasimhanii: a. Basal leaf \& flowering twig; b. Flower; c. Calyx; d \& e. Petal-dorsal and ventral views; f. Staminal column and stamens; g. Pistil; h \& i. Young \& mature schizocarps; j. Mericarp; k. Seed. 
Table 1: Comparison of diagnostic characters of A. persicum var. narasimhanii with typical variety:

\begin{tabular}{|l|l|l|}
\hline Characters/ Parts & A. persicum var. narasimhanii & A. persicum var. persicum \\
\hline Flowering pedicels & C. $5 \mathrm{~mm}$ long above the point of articulation & $10-20 \mathrm{~mm}$ long above the point of articulation \\
\hline \multirow{2}{*}{ Fruiting pedicels } & $\begin{array}{l}5-10 \mathrm{~mm} \text { long above the point of } \\
\text { articulation }\end{array}$ & $10-25 \mathrm{~mm}$ long above the point of articulation \\
\hline \multirow{2}{*}{ Calyx } & $\begin{array}{l}\text { Covers less than } 1 / 2 \text { or } 1 / 2 \text { the length of the } \\
\text { schizocarp }\end{array}$ & Covers $3 / 4^{\text {th }}$ or more the length of the schizocarp \\
\hline Ovary & $(6-)$ 7-8 (-9)-locular & 5 locular \\
\hline Style and Stigma & $(6-) 7-8(-9)$ & 5 \\
\hline Schizocarps & Infundibuliform, $2-2.5 \mathrm{~cm}$ across & Campanulate, 1.2-2 cm across \\
\hline \multirow{2}{*}{ Mericarps } & $(6-)$ 7-8 (-9) & Usually 5 \\
\cline { 2 - 4 } & Awns 0.7-1 mm long & Awns c. $3 \mathrm{~mm}$ long \\
\hline
\end{tabular}

trichomes outside, stellate with adpressed simple trichomes inside; tube 3-4 mm long, 5-lobed; lobes ovate-lanceolate, $6-10 \times 4-5 \mathrm{~mm}$, acute-acuminate at apex; fruiting calyx covering half or less than half of the schizocarp, persistent. Petals 5, twisted, spreading, broadly obovate, $c .1 .8 \times 1 \mathrm{~cm}$, cuneate at base, rounded-truncate at apex, glabrous inside, sparsely stellate with simple trichomes outside. Stamens c. 50; staminal column c. $5 \mathrm{~mm}$ long, conical and glabrous at base, narrow and stellate-hirsute at apex; filaments 1-2.2 cm long, purple; anthers reniform, c. $3 \times 2 \mathrm{~mm}$, basifixed, tuberculate. Ovary oblong-ovoid, c. $3 \mathrm{~mm}$ across, stellate-tomentose, (6-) 7 or 8 (-9) locular; styles (6-) 7 or 8 (-9), c. 2.5 $\mathrm{cm}$ long, free, shortly connate at base, greenish yellow; stigma (6-) 7 or 8 (-9), capitate. Schizocarps infundibuliform, $2-2.5 \mathrm{~cm}$ across, stellate-tomentose on sides, hirsute on ribs; mericarps (6-) 7 or $8(-9)$, c. $20 \times 5 \mathrm{~mm}$, abruptly acute at apex; acumen $0.7-1$ mm long; seeds 4 or 5 per mericarp, reniform, c. $3 \times$ $2.3 \mathrm{~mm}$, tuberculate, glabrous, brown.

Flowering $\mathcal{E}$ fruiting: December-May; peak during January-March.

Etymology: This taxon is named after Dr. D. Narasimhan, former Professor of Botany, Madras Christian College, Chennai for his valuable contribution in the fields of plant taxonomy, biodiversity and conservation biology for the past 25 years.

Habitat \& ecology: Abutilon persicum var. narasimhanii is growing on the margins of deciduous forests and forest-cleared open lands at elevation ranging from 800 to $1100 \mathrm{~m}$. This taxon is seen growing in association of the following species: Aphanamixis polystachya (Wall.) R.Parker, Chromolaena odorata (L.) R.M. King \& H.Rob., Excoecaria robusta Hook.f. var. crenulata (Wight) Chakrab. \& M. Gangop., Jasminum flexile Vahl, Lantana camara L. and Myristica beddomei subsp. sphaerocarpa W.J.de Wilde.

Distribution: India (Kolli Hills, Tamil Nadu) and Myanmar (?).

Additional specimens examined: INDIA, Tamil Nadu, Namakkal district, Kolli Hills, Ghat Road, 800 m, 11.01.1982, K.M. Matthew, S.J. Britto \& N. Rani 28796

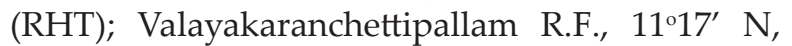
78'17' E, 1000 m, 02.04.1994, M.B. Viswanathan 3312 (FRLH); Seekupaarai view point slopes, $11^{\circ} 17^{\prime} 008^{\prime \prime}$ N, E 78'19'021", 1056 m, 19.03.2016 Devanathan 10403; Vilaram (Settur), 22.03.2016, 11 ${ }^{\circ} 13^{\prime} 460^{\prime \prime} \mathrm{N}$, 78'24'380" E, 869 m, 22.03.2016, Devanathan 10478;

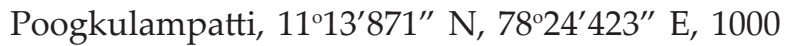
m, 23.02.2018, Devanathan \& D. Narasimhan 11215 (MCCH). MYANMAR (?). s.loc., s.die, s.coll. 138 (Acc. No.53848) (CAL).

Notes: In CAL, the folder labeled Myanmar under Abutilon persicum contains a single sheet with out details of locality, date and collector. It is difficult to ascertain whether the specimen belongs to Myanmar and hence the author has indicated the locality with a question mark in parenthesis.

\section{Acknowledgements}

I thank Dr. R.K. Upadhyay, IFS, PCCF (Research) and officials of Namakkal Forest Division, Tamil Nadu Forest Department for permission; Dr. I. Oliver King, Principal Scientist, M.S. 
Swaminathan Research Foundation, Namakkal, for help during the field visits; Mr. Kreni Lokho, Research scholar, Madras Christian College for designing the illustration plate; Dr. A.K. Pradeep, Assistant Professor of Botany, Calicut University, Kerala, for his opinion on the identification; Curators of Central National Herbarium, Botanical Survey of India (BSI), Howrah. The Rapinat Herbarium (RHT), St. Joseph's College, Tiruchirappalli; Madras Herbarium (MH), Southern Regional Centre, BSI, Coimbatore; Calicut University Herbarium (CALI) and Herbarium of Foundation for Revitalisation Local and Traditional Health (FRLH), Bangalore, for permission to access specimens.

\section{Literature Cited}

Borssum Waalkes, J. Van 1966. Malesian Malvaceae revised. Blumea 14(1): 1-213.

Britto, S.J. \& K.M. Matthew 1983. Malvaceae. In: Matthew, K.M. (ed.), The Flora of the Tamilnadu Carnatic. Vol. 3(1). The Rapinat Herbarium, St. Joseph's College, Tiruchirappalli. pp. 101-135.

Dunn, S.T. 1915. Malvaceae. In: Gamble, J.S. (ed.), Flora of the Presidency of Madras. Adlard \& Son Ltd., London. pp. 86-102.
Mabberley, D.J. 2017. Mabberley's Plant-Book: A portable dictionary of plants, their classification and uses. Fourth Edition. Cambridge University Press, Cambridge.

Paul, T.K. 1993. Malvaceae. In: Sharma, B.D. \& M. Sanjappa (eds.), Flora of India. Vol. 3. Botanical Survey of India, Kolkata. pp. 257-394.

Pullaiah, T. \& D.M. Rao 2002. Flora of Eastern Ghats Hill Ranges of South East India. Vol. 1. Regency Publications, New Delhi. pp. 121-122.

Singh, P., Karthigeyan, K., Lakshminarasimhan, P. \& S.S. Dash 2015. Endemic Vascular Plants of India. Botanical Survey of India, Kolkata.

Sivarajan, V.V. \& A.K. Pradeep 1996. Malvaceae of Southern Peninsular India: A Taxonomic Monograph. Daya Publishing House, Delhi. pp. 312.

Received: 29.07.2018

Revised and Accepted: 25.12.2018 